\section{Adenocarcinoma of the Lung in a 32-Year-Old Man: Is It Worthwhile to Check for Lung Cancer in Young Adults?}

Lung cancer in young ( $\leq 45$ years) adults is rare and constitutes $5-10 \%$ of all lung cancer cases. Because of underestimation of diagnosis in young age, these patients tend to present with advanced stages of carcinoma. This delayed diagnosis results in a rapid progression and a short survival time $[1,2]$. Lung cancer risk in young and older age groups shows remarkable differences with respect to sex and histologic type. Adenocarcinomas are more frequent than epidermoid and small-cell types. The male/female ratio is lower in young patients than in older age groups. Younger patients rarely have chronic obstructive lung disease, which is a reason for non-small-cell lung cancer being inoperable. That makes the young patients with lung cancer more curable if diagnosed at early stage. A high percentage of younger patients has not smoked heavily or for a long time, suggesting that risk factors other than smoking may be involved in lung carcinogenesis [3-5].

In May 2001, a 32-year-old man was admitted to the Clinic with coughing, weight loss, and fatigue having lasted for 4 months. He was a non-smoker with a non-significant medical history. Chest $\mathrm{x}$-ray showed a right hilus shadow. Computed tomography of the thorax disclosed a mass of $3 \times 4 \times 5 \mathrm{~cm}$ located at the right hilum around the right main bronchus, with multiple lymphadenopathies, the largest one $2.5 \mathrm{~cm}$. Bronchoscopy was performed and showed a mass seeming to be originating from submucosa at intermediary bronchus in the right lung. Histopathological examination revealed that it was an adenocarcinoma. He seemed to have stage IIIB inoperable disease and his performance status was ECOG 1.

It is important to consider lung cancer in young patients experiencing coughing, hoarseness, hemoptysis, anorexia, weight loss, dyspnea, refractory pneumonia or when they present with abnormal shadow on chest radiograph even in the absence of a smoking habit. Because younger patients rarely have chronic obstructive lung disease, a reason for non-smallcell lung cancer being inoperable, young patients with lung cancer seem to be more curable if diagnosed at an early stage.
2 Liu NS, Spitz MR, Kemp BL, et al: Adenocarcinoma of the lung in young patients: The M. D. Anderson experience. Cancer 2000;15;88:1837-1841.

3 Lienert T, Serke M, Schonfeld N, Loddenkemper R: Lung cancer in young females. Eur Respir J 2000;16;:986-990.

4 Kuo CW, Chen YM, Chao JY, Tsai CM, Perng RP: Non-small cell lung cancer in very young and very old patients. Chest 2000;117:354-357.

5 Veness MJ, Delaney G, Berry M: Lung cancer in patients aged 50 years and younger: Clinical characteristics, treatment details and outcome. Australas Radiol 1999;43:328-333.

L. Filik ${ }^{a}$, O. Ozyilkan ${ }^{b}$

aBayindir Tip Merkezi-Medical Centre, Sogutozu, Ankara, Turkey

${ }^{b}$ Baskent University, Division of Oncology, Ankara, Turkey

(for correspondence: see below)

\title{
References
}

1 Ramalingam S, Pawlish K, Gadgeel S, Demers R, Kalemkerian GP: Lung cancer in young patients: Analysis of a Surveillance, Epidemiology, and End Results database. J Clin Oncol 1998;16:651-657.

\begin{tabular}{ll}
\hline KARGER & ( ) 2002 S. Karger GmbH, Freiburg \\
Fax +49 7614520714 & Accessible online at: \\
$\begin{array}{l}\text { E-mail Information@Karger.de } \\
\text { www.karger.com }\end{array}$ & www.karger.com/journals/onk
\end{tabular}

